\title{
APLIKASI PENGOLAHAN CITRA UNTUK IDENTIFIKASI KEMATANGAN MENTIMUN BERDASARKAN TEKSTUR KULIT BUAH MENGGUNAKAN METODE EKSTRAKSI CIRI STATISTIK
}

\author{
${ }^{1}$ Yuda Permadi, ${ }^{2}$ Murinto \\ Program Studi Teknik Informatika \\ Kampus III J1.Prof. Dr. Soepomo, Janturan, Warungboto, Yogyakarta. \\ Universitas Ahmad Dahlan \\ ${ }^{1}$ Email :funktastic@ymail.com \\ ${ }^{2}$ Email :murintokusno@yahoo.com
}

\begin{abstract}
Abstrak
Mentimun (Cucumis sativus L) merupakan buah yang dapat dikonsumsi dan dapat diolah lebih lanjut sebagai bahan baku pada industri kecantikan, dan memiliki pangsa pasar yang luas mulai dari pasar tradisional hingga pasar modern. Adanya kemiripan tekstur kulit mentimun antara yang matang dengan yang belum matang mengakibatkan orang kesulitan dalam mengidentifikasi mentimun matang dari segi ciri tekstur kulit buah dan penilaian manusia yang bersifat subyektif terhadap tingkat kematangan buah mentimun menyebabkan penilaian tingkat kematangan mentimun berbeda dari satu penilai dengan penilai yang lainnya. Dari permasalahan tersebut, sehingga dilakukan penelitian untuk mendeteksi kematangan mentimun berdasarkan tekstur kulit buah. Tujuan dari penelitian ini adalah menerapkan metode statistik dengan parameter ciri yaitu Mean $(\mu)$, Variance $\left(\sigma^{\wedge} 2\right)$, Skewness ( $\left.\alpha \_(3)\right)$, Kurtosis ( $\left.\alpha \_(4)\right)$, dan Entropy (H) sebagai metode untuk mengenali kematangan mentimun dari segi tekstur kulit buah dan untuk mengetahui nilai akurasi setelah sistem diuji. Subyek penelitannya adalah membangun aplikasi pengolahan citra untuk mendeteksi ukuran buah mentimun matang secara statistik dari segi tekstur kulit buah. Data dalam penelitian ini menggunakan citra buah mentimun yang diambil dengan kamera kemudian dilakukan pemotongan ukuran (cropping) menjadi 512 x 512 pixels dan penggantian format citra menjadi *.bmp. Metode pengumpulan data yang digunakan adalah metode studi literatur dengan menggunakan data-data dari buku, e-book, penelitian terdahulu, literatur dari internet, metode observasi dengan mengambil dan mengamati citra buah mentimun, metode dokumentasi dengan pengumpulan data secara langsung, dan wawancara terhadap petani dan penjual buah mentimun untuk memastikan data yang diperoleh mengenai informasi buah mentimun sesuai dengan fakta yang ada. Berdasarkan hasil pengujian dengan menggunakan 20 sampel yang terdiri dari 10 citra mentimun matang dan 10 citra mentimun belum matang menunjukkan bahwa hasil untuk pengujian mentimun matang mencapai 70\%, sedangkan untuk mentimun belum matang mencapai $80 \%$. Secara keseluruhan tingkat keberhasilan aplikasi pengolahan citra untuk identifikasi kematangan mentimun berdasarkan tekstur kulit buah dengan metode ekstraksi ciri statistik yaitu sebesar $75 \%$.
\end{abstract}

Kata kunci : Ekstraksi Ciri, Kematangan Mentimun, Pengolahan Citra.

\section{PENDAHULUAN}

Mentimun, timun, atau ketimun (Cucumis sativus L) merupakan buah yang mempunyai nilai komersial di Indonesia, dan memiliki pangsa pasar yang luas mulai dari pasar tradisional hingga pasar modern.Hal ini menunjukkan bahwa komoditas mentimun 
sudah dikonsumsi masyarakat secara luas dan memiliki daya saing.Dalam rangka meningkatkan daya saing tersebut maka buah mentimun yang dihasilkan harus dapat memenuhi standar pasar dalam negeri maupun pasar internasional dan di terima secara luas oleh konsumen.

Industri pengolahan hasil pertanian dan perkebunan sangat berkembang pesat.Kegiatan pasca panen erat kaitannya dengan mutu produk yang dihasilkan, yang pada akhirnya menentukan pula harga jual yang dapat diterima oleh petani.Salah satu tahap dalam proses pengolahan hasil perkebunan pasca panen adalah pemilahan produk berdasar kualitasnya yang dapat menjamin keseragaman mutu. Mutu buah mentimun ditentukan oleh berbagai parameter diantaranya adalah parameter tingkat usia tanam, bentuk dan ukuran fisik, serta kematangannya (Kementerian Pertanian, 2008).

\section{LANDASAN TEORI}

\subsection{Citra}

Citra merupakan istilah lain untuk gambar sebagai salah satu komponen multimedia yang memegang peranan yang sangat penting sebagai bentuk informasi visual. Citra mempunyai karakteristik yang tidak dimiliki oleh data teks, yaitu citra kaya dengan informasi.

Secara harfiah, citra (image) adalah gambar pada bidang dwimatra (dua dimensi). Ditinjau dari sudut pandang matematis, citra merupakan fungsi menerus (continue) dari intensitas cahaya pada bidang dwimatra. Sumber cahaya menerangi objek, objek memantulkan kembali sebagai dari berkas cahaya tersebut.Pantulan cahaya ini ditangkap oleh alat-alat optik, misalnya mata pada manusia, kamera, pemindai (scanner), dan sebagainya.Sehingga bayangan objek yang disebut citra tersebut terakam(Rinaldi Munir, 2004).

\subsection{Tekstur Citra (Texture)}

Tekstur dicirikan sebagai distribusi spasial dari derajat keabuan didalam sekumpulan pixel-pixel yang bertetangga. Jadi, tekstur tidak dapat diidentifikasikan untuk sebuah pixel, melaikan suatu citra dianggap sebagai suatu kesatuan. Dapat pula dikatakan bahwa tekstur (texture) adalah sifat sifat atau karakteristik yang dimiliki oleh suatu daerah yang cukup besar sehingga secara alami sifat tersebut dapat berulang dalam daerah tersebut. Pengertian dari tekstur dalam hal ini adalah keteraturan pola-pola tertentu yang terbentuk dari susunan pixel-pixel dalam citra. Suatu permukaan dikatakan mempunyai informasi tekstur, jika luasannya diperbesar tanpa mengubah skala, maka sifat-sifat permukaan hasil perluasan mempunyai sifat kemiripan dengan permukaan asalnya.

Pola-pola yang teratur muncul secara berulang-ulang dengan interval jarak dan arah yang tertentu. Suatu permukaan tak berwarna dalam suatu citra dapat mengandung informasi tekstur bila permukaan itu mempunyai pola-pola tertentu seperti permukaan kayu bekas di gergaji, permukaan batu, hamparan pasir, kumpulan biji-bijian, dan sebagainya. Informasi tekstur dapat digunakan untuk membedakan sifat permukaan suatu benda dalam citra yang berhubungan dengan kasar dan halus, sifat-sifat spesifik dari kekasaran dan kehalusan permukaan tersebut, yang sama sekali lepas dari warna permukaan tersebut.

Analisis tekstur lazim dimanfaatkan sebagai proses antara untuk melakukan klasifikasi dan interpretasi citra. Suatu proses klasifikasi citra berbasis analisis tekstur pada umumnya membutuhkan tahapan ekstraksi ciri, yang dapat terbagi dalam tiga macam metode yaitu metode statistik, metode spektral dan metode struktural. Metode statistik menggunakan perhitungan statistik distribusi derajat keabuan (histogram) dengan mengukur tingkat kekontrasan, granularitas, dan kekasaran suatu daerah dari hubungan ketetanggaan antar piksel di dalam citra. Paradigma statistik ini penggunaannya tidak 
terbatas, sehingga sesuai untuk tekstur-tekstur alami yang tidak terstruktur dari sub pola dan himpunan aturan (mikrostruktur) (Siska Riantini Arief, 2011).

\subsection{Ekstraksi Ciri Statistik}

Ekstraksi ciri merupakan metode pengambilan ciri yang didasarkan pada karakteristik histogram citra.Histogram menunjukkan probabilitas kemunculan nilai derajat keabuan piksel pada suatu citra. Dari nilai-nilai pada histogram yang dihasilkan, dapat dihitung beberapa parameter ciri, antara lain adalah mean, variance, skewness, kurtosis, dan entropy(Abdul Fadlil, 2012).

a. Mean $(\mu)$

Menunjukkan ukuran dispersi dari suatu citra

Dimana :

$$
\mu=\sum_{\mathrm{n}=0}^{\mathrm{N}} \mathrm{f}_{\mathrm{n}} \mathrm{p}\left(\mathrm{f}_{\mathrm{n}}\right)
$$

$$
\begin{array}{ll}
f_{n} & =\text { nilai intensitas keabuan } \\
\mathrm{p}\left(\mathrm{f}_{\mathrm{n}}\right) & =\text { nilai histogram }
\end{array}
$$

b. Variance ( $\sigma 2)$

Menunjukkan variasi elemen pada histogram dari suatu citra

$$
\sigma^{2}=\sum_{n=0}^{N}\left(f_{n}-\mu\right)^{2} p\left(f_{n}\right)
$$

Dimana :

$$
\begin{array}{ll}
f_{n} & =\text { nilai intensitas keabuan } \\
\mu & =\text { nilai mean } \\
\mathrm{p}\left(\mathrm{f}_{\mathrm{n}}\right) & =\text { nilai histogram }
\end{array}
$$

c. Skewness $\left(\alpha_{3}\right)$

Menunjukkan tingkat kemencengan relatif kurva histogram dari suatu citra

$$
\alpha_{3}=\frac{1}{\sigma^{3}} \sum_{\mathrm{n}=0}^{\mathrm{N}}\left(\mathrm{f}_{\mathrm{n}}-\mu\right)^{3} \mathrm{p}\left(\mathrm{f}_{\mathrm{n}}\right)
$$

Dimana :

$$
\begin{array}{ll}
\sigma^{3} & =\text { standar deviasi dari nilai intensitas keabuan } \\
f_{n} & =\text { nilai intensitas keabuan } \\
\mu & =\text { nilai mean } \\
\mathrm{p}\left(\mathrm{f}_{\mathrm{n}}\right) & =\text { nilai histogram }
\end{array}
$$

d. Kurtosis $\left(\alpha_{4}\right)$

Menunjukkan tingkat keruncingan relatif kurva histogram dari suatu citra

Dimana :

$$
\alpha_{4}=\frac{1}{\sigma^{4}} \sum_{\mathrm{n}=0}^{\mathrm{N}}\left(\mathrm{f}_{\mathrm{n}}-\mu\right)^{4} \mathrm{p}\left(\mathrm{f}_{\mathrm{n}}\right)-3
$$

$$
\begin{array}{ll}
\sigma^{4} & =\text { standar deviasi dari nilai intensitas keabuan } \\
f_{n} & =\text { nilai intensitas keabuan } \\
\mu & =\text { nilai mean } \\
\mathrm{p}\left(\mathrm{f}_{\mathrm{n}}\right) & =\text { nilai histogram }
\end{array}
$$

e. Entropy (H)

Menunjukkan ukuran ketidakaturan bentuk dari suatu citra

$$
H=-\sum_{n=0}^{N} p\left(f_{n}\right) \cdot{ }^{2} \log p\left(f_{n}\right)
$$


Dimana :

$$
\mathrm{p}\left(\mathrm{f}_{\mathrm{n}}\right)=\text { nilai histogram }
$$

\subsection{Kematangan Mentimun}

Umur panen tanaman mentimun tergantung dari varietas dan ukuran buah yang dikehendaki. Pada umumnya buah mentimun dapat dipanen pada umur 60-75 hari setelah tanam. Ciri-ciri mentimun sudah matang adalah setelah terjadi perubahan warna buah dan ukuran fisik buah yang bertambah panjang dan lebih besar maka buah tersebut bisa dipanen (Kementerian Pertanian, 2008). Mentimun matang dilihat dari segi teksturnya ialah tekstur garisnya lebih halus (smooth) dibandingkan dengan mentimun belum matang yang memiliki tekstur garis lebih tajam dan kasar, sedangkan dari sisi jumlah sebaran teksturnya mentimun matang memiliki sebaran lebih sedikit dibandingkan dengan mentimun belum matang.

\section{METODE PENELITIAN}

Metode penelitian merupakan suatu cara ilmiah yang digunakan untuk memperoleh dan menyelesaikan suatu masalah yang dilandasi oleh metode ilmiah. Subjek dari penelitian ini adalah mengetahui tekstur citra mentimun belum matang dan matang dengan menggunakan 5 parameter ciri yaitu mean, variance, skewness, kurtosis, dan entropy dengan menggunakan Matlab v8.2. Data dalam penelitian ini menggunakan 40 sampel citra truecolor 24bit dengan format ekstensi *.bmp yang terdiri masing-masing 20 citra pada tekstur kulit mentimun matang dan belum matang.

\section{HASIL PENELITIAN DAN PEMBAHASAN}

\subsection{Perancangan Sistem}

Berikut perancangan flowchart dari aplikasi pengolahan citra untuk identifikasi kematangan mentimun berdasarkan tekstur kulit buah dengan metode ekstraksi ciri statistik :

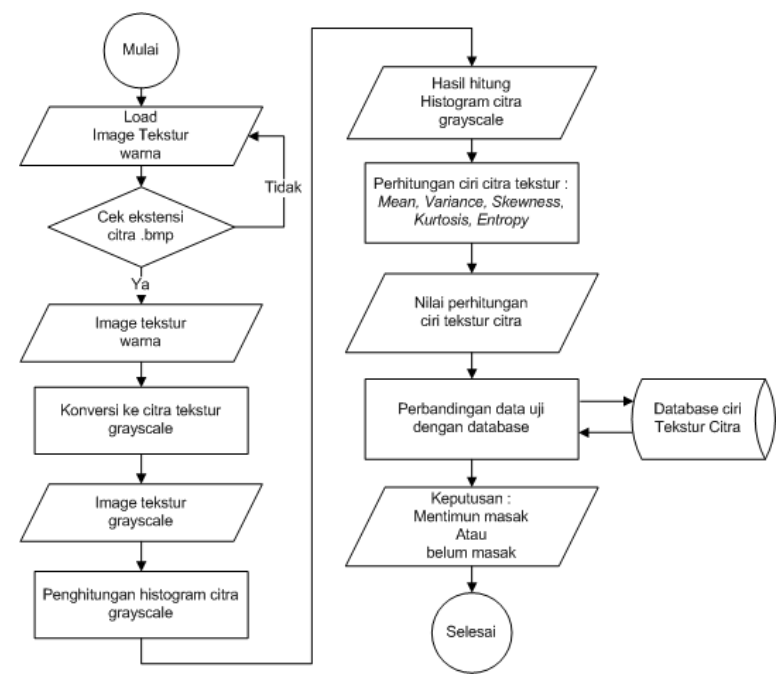

Gambar 4.1. Flowchartaplikasi deteksi kematangan mentimun

\subsection{Implementasi Sistem}

Sebelum membuat program utama, perlu dibuat database sebagai penyimpanan data perhitungan statistik tekstur citra yang menjadi pembanding untuk citra 
pengujian sehingga didapatkan kesimpulan untuk citra pengujian tersebut apakah termasuk citra mentimun yang matang atau belum matang.

Pembuatan database menggunakan masing-masing 10 citra dari tekstur kulit mentimun matang dan tekstur kulit mentimun belum matang, dengan menghitung nilai lima parameter ciri yaitu mean, variance, skewness, kurtosis dan entropy. Database ini disimpan dalam bentuk tabel dengan format *.mat, yaitu format default penyimpanan workspace pada aplikasi Matlab.Kurva perhitungan parameter ciri untuk tekstur kulit mentimun matang pada database dapat dilihat pada Gambar 4.2. di bawah ini:

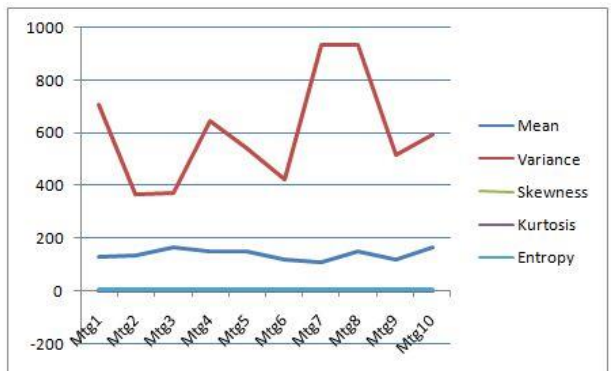

Gambar 4.2. Kurva Ciri Tekstur Kulit Mentimun Matang

Kurva perhitungan parameter ciri untuk tekstur kulit mentimun belum matang pada database dapat dilihat pada Gambar 3. di bawah ini:

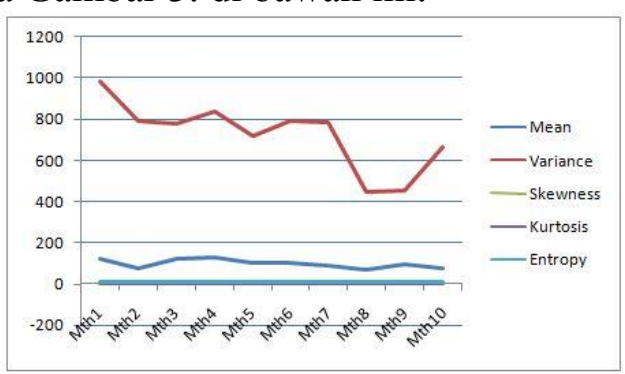

Gambar 4.3. Kurva Ciri Tekstur Kulit Mentimun Belum Matang

Setelah semua nilai parameter diketahui, lalu dilakukan pencarian nilai rata-rata pada setiap parameter untuk setiap citra tekstur kulit mentimun matang dan belum matang. Berikut ini adalah Tabel 4.1. yang berisi hasil perhitungan rata-rata dari setiap parameter yang menjadi range ciri kematangan citra tekstur kulit mentimun :

Tabel 4.1.Range Kematangan Mentimun

\begin{tabular}{|l|c|c|c|c|c|c|}
\hline \multirow{2}{*}{ Range } & \multicolumn{7}{|c|}{ Parameter Ciri } \\
\cline { 2 - 6 } & Mean & Variance & Skewness & Kurtosis & Entropy & Keterangan \\
\hline Average & 97,98 & 726,84 & 0,63 & 0,38 & 6,68 & \multirow{2}{*}{$\begin{array}{c}\text { Belum } \\
\text { Matang }\end{array}$} \\
\hline Min & 69,42 & 447,30 & 0,28 & $-0,41$ & 6,28 & \\
\hline Max & 127,06 & 986,02 & 1,08 & 1,78 & 6,96 & \\
\hline Average & 139,04 & 604,79 & 0,10 & $-0,29$ & 6,60 & \multirow{2}{*}{$\begin{array}{c}\text { Mentimun } \\
\text { Matang }\end{array}$} \\
\hline Min & 110,83 & 424,50 & $-0,45$ & $-0,54$ & 6,28 & \\
\hline Max & 163,28 & 935,22 & 0,35 & 0,23 & 6,95 & \\
\hline
\end{tabular}

Tampilan halaman depan aplikasi pengolahan citra untuk identifikasi kematangan mentimun berdasarkan tekstur kulit buah dengan metode ekstraksi ciri statistik yaitu seperti Gambar 4.4. dibawah ini : 


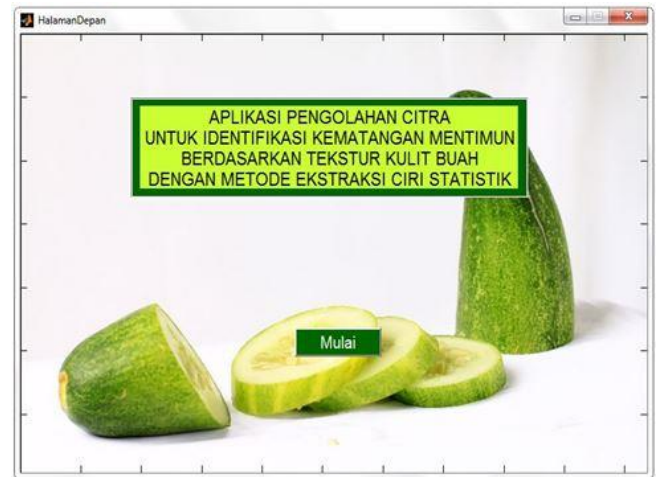

Gambar 4.4. Tampilan Halaman Depan Aplikasi

Tampilan utama aplikasi dapat dilihat pada gambar 4.5. Di bawah ini :

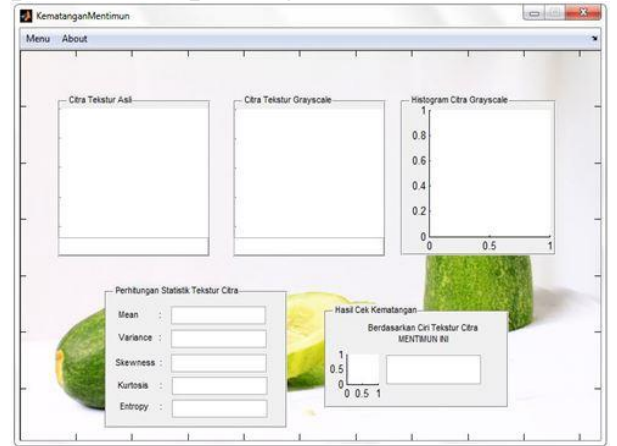

Gambar 4.5. Tampilan Utama Aplikasi

Dalam perancangan sistem ini ada prosedur utama yang akan dibuat yaitu :

\section{Load image}

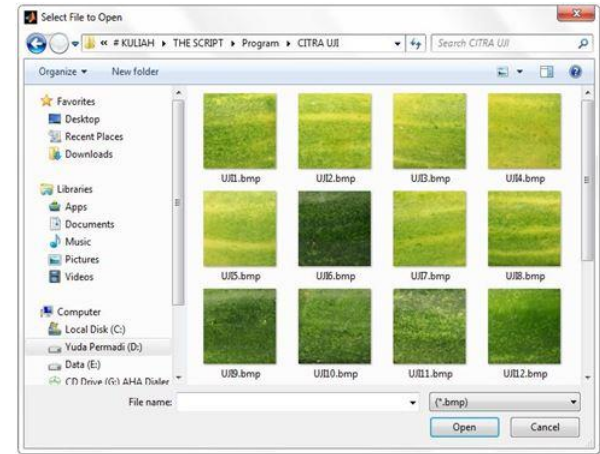

Gambar 4.6.Tampilan Untuk Membuka dan Menampilkan File Citra

Pada bagian proses load ini, hanya file citra yang berekstensi *.bmp yang dapat diload dan ditampilkan pada program. Setelah memilih gambar dengan memilih menu Load Image, maka file citra akan ditampilkan pada tempat yang telah disediakan, seperti pada gambar 4.7. dibawah ini : 


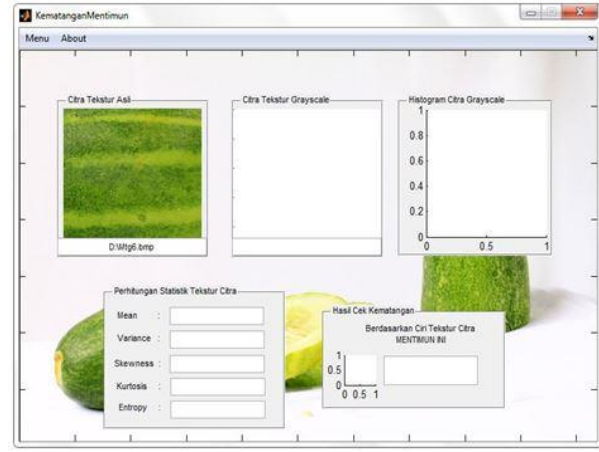

Gambar 4.7.Tampilan Setelah File Berhasil dibuka

2. Konversi Grayscale

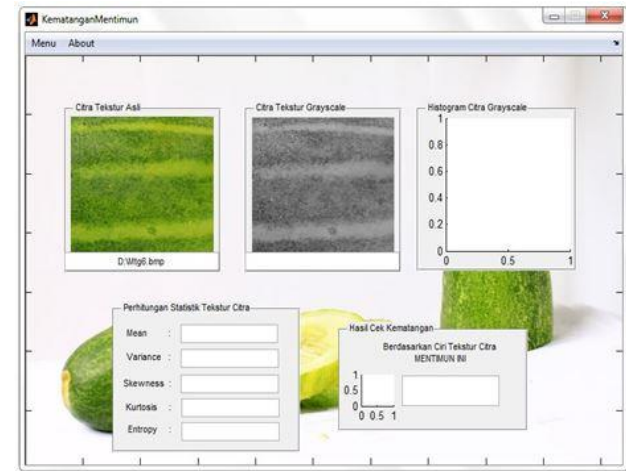

Gambar 4.8. Tampilan Konversi Citra grayscale

3. Histogram CitraGrayscale

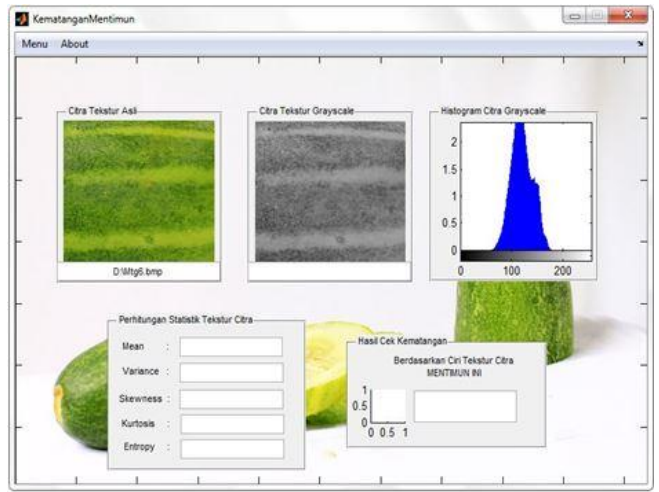

Gambar 4.9. Tampilan Histogram Citra Grayscale

4. Perhitungan Statistik Tekstur Citra

Proses selanjutnya ialah ekstraksi ciri tekstur citra, dimana setelah citra telah terkonversi ke grayscale dan dihitung histogramnya, maka selanjutnya akan muncul nilai mean, variance, skewness, kurtosis, dan entropy seperti Gambar 4.10. dibawah ini : 


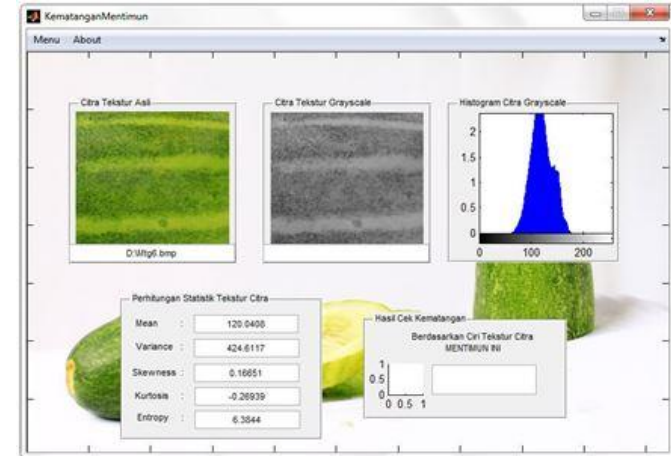

Gambar 4.10. Tampilan Ciri Tekstur Citra

5. Menampilkan Hasil Cek Kematangan

Proses terakhir adalah menampilkan keputusan apakah citra tekstur mentimun yang diuji adalah mentimun matang atau belum matang seperti Gambar 4.11. di bawah ini:

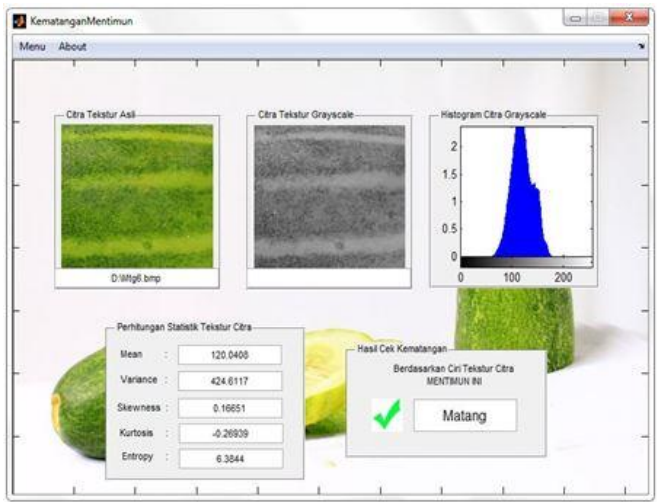

Gambar 4.11.Tampilan Hasil Cek Kematangan

\subsection{Pengujian Sistem}

Dalam penelitian ini tahap pengujian sistem akan dilakukan dengan melakukan pengujian terhadap 20 citra yang berekstensi *bmp. Dari 20 data citra tersebut akan dicari nilai parameter teksturnya yaitu mean, variance, skewness, kurtosisdan entropy. Dimana telah diambil sampel sebanyak 10 buah pada masing-masing tekstur kulit mentimun yaitubelum matang dan mentimun matang.Citra mentimun dengan format bitmap dikonversi ke bentuk grayscaledan ditampilkan histogram grayscale-nya. Dihitung mean, variance, skewness, kurtosis, dan entropy. Perhitungan 5 parameter tersebut mampu mendeteksi tekstur kulit mentimun dengan membandingkan data range nilai rata-rata tekstur kulit mentimun yang menjadi acuan dalam menentukan tekstur kulit mentimun yang matang. Tabel hasil deteksi kematangan mentimun berdasarkan tekstur kulit buah dapat dilihat pada Tabel 4.2. berikut : 
Tabel 4.2..Hasil Deteksi Kematangan Mentimun.
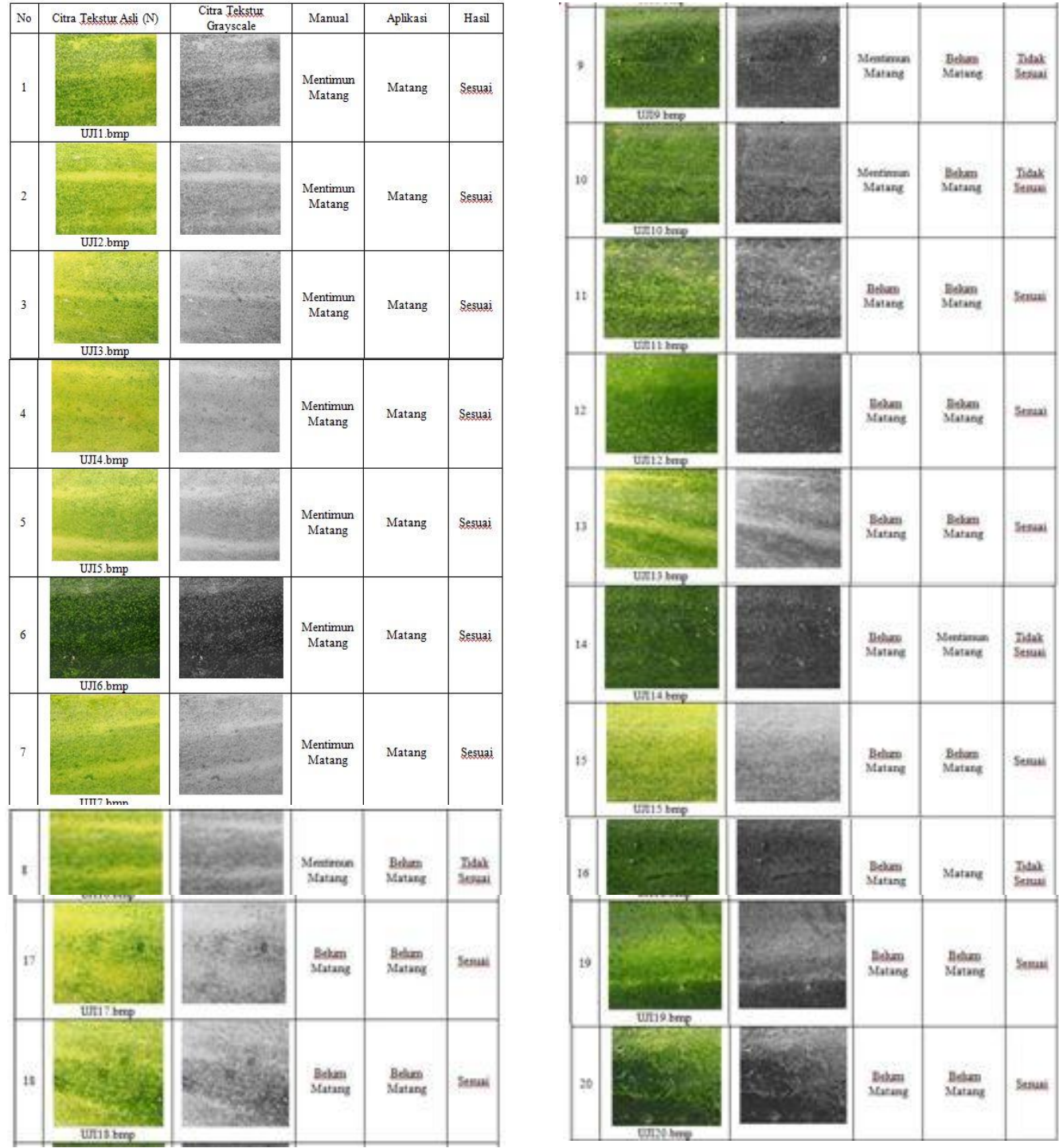

Dimana nilai $\mathrm{N}$ adalah jumlah seluruh citra mentimun yang diujikan yaitu 20 citra yang terdiri dari 10 citra mentimun matang dan 10 citra mentimun belum matang. maka dapat dihitung tingkat akurasinya sebagai berikut :

Diketahui $: \mathrm{N}=20$, Hasil yang sesuai $=15$, Hasil yang tidak sesuai $=5$ maka akurasi sistem ini dapat dilihat pada Tabel 4.3. :

Tabel 4.3.Akurasi Sistem

\begin{tabular}{|c|c|c|}
\hline \multicolumn{3}{|c|}{ Data uji } \\
\hline Input & Sesuai & Tidak sesuai \\
\hline $\begin{array}{c}\text { Mentimun } \\
\text { Matang }\end{array}$ & 7 & 3 \\
\hline $\begin{array}{c}\text { Belum } \\
\text { Matang }\end{array}$ & 8 & 2 \\
\hline & $=\frac{\text { Jumlah citra uji yang sesuai }}{N} \times 100 \%$ \\
Akurasi(\%) & $\begin{array}{l}|c| \\
=\frac{15}{20} \times 100 \% \\
=75 \%\end{array}$ \\
\hline
\end{tabular}

Dari tabel akurasi sistem tersebut didapatkan tingkat akurasi untuk identifikasi kematangan mentimun berdasarkan perhitungan tekstur citra dengan metode ekstraksi ciri statistik yaitu mencapai $75 \%$. 


\section{KESIMPULAN DAN SARAN}

\section{Kesimpulan}

Berdasarkan hasil penelitian yang telah dilakukan dapat diambil kesimpulan sebagai berikut :

a. Selain dari usia tanam, segi warna kulit, dan ukuran fisik buah, mentimun juga bisa diketahui kematangannya dari sisi tekstur kulitnya.

b. Dari lima parameter ekstraksi ciri yang digunakan yaitu Mean $(\mu)$, Variance $\left(\sigma^{2}\right)$, Skewness $\left(\alpha_{3}\right)$, Kurtosis $\left(\alpha_{4}\right)$, danEntropy $(H)$, dapat dilihat dan disimpulkan bahwa parameter Variance $\left(\sigma^{2}\right)$ adalah parameter yang paling berpengaruh dalam penentuan ciri citra karena terlihat pada ukuran nilainya yang sangat fluktuatif (lihat Gambar 4.2. dan Gambar 4.3.).

c. Kendala yang muncul dari penggunaan metode ekstraksi ciri untuk mengukur nilai statistik citra tekstur kulit buah mentimun salah satunya adalah teknik pengambilan data. Citra yang blurr dapat mempengaruhi nilai perhitungan yang dilakukan. Hal ini dapat dilihat pada pengujian citra UJI14 dan citra UJI16 (lihat Tabel 4.2.) dimana dua citra uji tersebut termasuk citra yang hasil pengujian aplikasi tidak sesuai dengan pengujian manual dikarenakan citra blurr. Pengambilan sampel pada proses pengumpulan data akan sangat mempengaruhi akurasi dari metode ini yang nantinya akan berdampak pada pengambilan kesimpulan.

d. Hasil deteksi kematangan dari aplikasi ini mempunyai persentase tingkat keberhasilan yang baik, untuk pengujian mentimun matang mencapai $70 \%$, sedangkan untuk mentimun belum matang mencapai $80 \%$. Secara keseluruhan tingkat keberhasilan Aplikasi pengolahan citra untuk identifikasi kematangan mentimun berdasarkan tekstur kulit buah dengan metode ekstraksi ciri statistik yaitu sebesar $75 \%$.

\section{Saran}

Penelitian ini tentu saja masih banyak kekurangan, karena itu diperlukan saran dan kritik yang nantinya dapat digunakan untuk lebih mengembangkan aplikasi ini. Adapun saransaran yang dapat digunakan untuk mengembangkan penelitian ini adalah sebagai berikut

a. Perlu dilakukan penelitian menggunakan metode ekstraksi ciri orde dua dengan parameter energy, contrast, correlation dan inverse different moment, sehingga dapat diketahui hasilnya dan dapat dibandingkan dengan parameter orde pertama yang pada akhirnya mendapatkan keputusan parameter ciri manakah yang lebih akurat untuk menghitung tekstur citra secara statistik.

b. Citra kulit mentimun yang digunakan ialah mentimun biasa/konsumsi, penulis menyarankan untuk dapat menggunakan citra tekstur mentimun jenis lain lain, misalnya citra mentimun krei, mentimun suri, dan jenis mentimun yang lain.

\section{DAFTAR PUSTAKA}

Anggraeni, Nur Tyas. 2012. Sistem Identifikasi Citra Jenis Cabai(Capsicum annum L) MenggunakanMetodeKlasifikasiCity Block Distance. Skripsi. Program Studi Teknik Informatika Universitas Ahmad Dahlan.

Arief, Siska Riantini. 2011. Analisis Tekstur dan Ekstraksi Ciri, Program Studi Teknik Informatika, Institut Teknologi Telkom Bandung.avalaible at: http://www.ittelkom.ac.id/.

Budiningsih, Rahayu. 2013. Aplikasi Pengolahan Citra Untuk Mendeteksi Mutu Buah Berdasarkan Kerusakan Jeruk Mengunakan Metode Thresholding. Skripsi. Yogyakarta : Program Studi Teknik Informatika Universitas Ahmad Dahlan. 
Fadlil, Abdul. 2012. Modul Kuliah Pengenalan Pola. Universitas Ahmad Dahlan, Yogyakarta.

Hasan, Talib Hashim. 2005. Belajar Sendiri Dasar-Dasar Pemrograman Matlab Lengkap Disertai Teori dan Aplikasi. Yogyakarta : Gava Media.

Kadir, Abdul dan Adhi Susanto. 2013. Teori dan Aplikasi Pengolahan Citra. Yogyakarta : ANDI.

Kementerian pertanian. 2008. Artikel Budidaya dan Klasifikasi Varietas Mentimun. Melalui : http://cybex.deptan.go.id/Timun.

Munir, Rinaldi. 2004. Pengolahan Citra Digital dengan pendekatan Algoritmik. Bandung : Informatika.

Putra, Darma. 2010. Pengolahan Citra Digital. Yogyakarta : ANDI. 